\title{
Persistent toxic substances in surface water of Todos Os Santos Bay, Brazil
}

\author{
Joil José Celino ${ }^{1, *}$, Henry Xavier Corseuil ${ }^{2}$, Marilda Fernandes ${ }^{2}$, Gisele Mara Hadlich ${ }^{1}$ \\ ${ }^{1}$ Laboratório de Estudos do Petróleo (LEPETRO), Núcleo de Estudos Ambientais (NEA), Instituto de Geociências da UFBA \\ (IGEO/UFBA), Rua Barão de Geremoabo, s/n-, Sala 304-A, Ondina. CEP 40170-115, Salvador, Bahia, Brazil \\ ${ }^{2}$ Laboratório de Remediação de Águas Subterrâneas (REMAS), Depto. de Engenharia Sanitária e Ambiental, Universidade Federal de \\ Santa Catarina (UFSC), Campus Universitário, Caixa-Postal: 476. CEP 88010-970, Florianópolis, Santa Catarina, Brazil
}

\begin{abstract}
Persistent toxic substances (PTSs) such as polycyclic aromatic hydrocarbons (PAHs) are of great concern due to their persistence, bioaccumulation and toxic effects. In this work, 14 PAHs included in the US Environmental Protection Agency's (EPA) priority pollutant list were analysed using gas chromatography-mass spectrometry (GC-MS). Surface water sampling was undertaken in Todos os Santos Bay, northern Brazil. Total PAH concentrations varied from 0.0029 to 0.1079 $\mathrm{ng} / \mathrm{L}$ in surface waters (main rivers, tributaries, etc.) with mean value of $0.0344 \mathrm{ng} / \mathrm{L}$. Such concentrations can be taken as background values for the studied region and show that PAHs are within or lower than levels reported in certain other areas. The PAH profiles were dominated by high molecular weight PAHs (four- and five-ring components) in surface water samples. It indicated that PAHs in surface water have its origin from oil or sewage contamination (petrogenic input). The collected data, based on indices among phenanthrene versus anthracene, showed that petrogenic input was predominant at almost all the stations investigated. Principal component analysis (PCA), using a correlation matrix, revealed the latent relationships among all the surface water stations investigated and confirmed our analytical results.
\end{abstract}

Keywords Polycyclic Aromatic Hydrocarbons (PAHs), Surface Water, Estuary, Gas Chromatography-Mass Spectrometry (GC-MS), Principal Component Analysis (PCA)

\section{Introduction}

Water pollution by organic compounds, many of which are known to be toxic or carcinogenic, has caused considerable and worldwide concern. Persistent toxic substances (PTSs) are semi-volatile chemicals that can be bioaccumulated by living organisms, that are resistant to degradation and that possess toxic properties[1-2]. Among PTS chemicals, PAHs (Polycyclic Aromatic Hydrocarbons) are important classes of compounds that have caused serious environmental problems. Polycyclic aromatic hydrocarbons (PAHs), hydrocarbons containing two or more fused benzene rings, are a group of ubiquitous organic pollutants of great environmental concern because of the documented carcinogenicity in experimental animals and the widespread occurrence of several of its members[3]. Due to their ubiquitous occurrence, recalcitrance and suspected carcinogenicity and mutagenicity[4], PAHs are included in the U.S. Environmental Protection Agency (EPA) and in the European Union priority lists of pollutants.

The US EPA fixed 16 parent PAHs as priority pollutants,

* Corresponding author:

joil@ufba.br (Joil José Celino)

Published online at http://journal.sapub.org/re

Copyright (C) 2012 Scientific \& Academic Publishing. All Rights Reserved the latest being effective from 1997[5-9], some of which are considered to be possible or probable to human carcinogens, and the endocrine disrupting activities of PAHs have been recently reported $[10,11]$. Therefore, their distributions in the environment and potential human health risks have become the focus of much attention.

Most surveys of PAH contamination in water bodies have been in conducted in North America and Europe, such as in USA[12-14], Canada[15], Germany[16-19], England[20], France[21], Greece[3] and other countries[22]. Information concerning water pollution with PAHs in South America has been reported for Brazil[23-25] and Chile[26]. The majority of these surveys worldwide were mainly focused on seawater (coastal of offshore) and estuarine water. However, few data are available for PAH contamination of the inland waters of Todos os Santos Bay, Bahia, which usually act as receptors for sewage, industrial effluents and urban or rural run off[27-28].

PAHs are introduced into the environment mainly as a consequence of incomplete combustion originated from both, natural and anthropogenic processes. However, in many areas affected by human activities, natural sources are overwhelmed by anthropogenic sources except perylene. Anthropogenic sources include both high and low temperature combustion of fossil fuels and the direct release of oil and its products. For parent PAHs, combustion and/or an- 
thropogenic input is often inferred from an increase in the proportion of the less stable, "kinetic" $\mathrm{PAH}$ isomers relative to the more stable, "thermodynamic" isomers and the stability of the lighter PAH isomers has been calculated to support such interpretations[29].

The ratios of $\mathrm{Ph} / \mathrm{An}$ within the two-ring $\mathrm{PAH}$ group and Fl/Py within four-ring PAH group were used to differentiate $\mathrm{PAHs}$ of distinct origins. $\mathrm{Ph}$ is more thermochemically stable than An, and therefore at low maturation temperatures much higher molar fraction of $\mathrm{Ph}$ is produced compared to $\mathrm{An}[30]$. These molar ratios of $\mathrm{Ph} / \mathrm{An}$ at petroleum maturation temperatures lead to higher values. It can be as high as 50 at $373 \mathrm{~K}$. On the other hand, high temperature processes (800-1000 K), such as the incomplete combustion of organic materials (coal burning, wood burning, vehicular exhaust emission, waste crankcase oil and asphalt roofing material), are characterized by low $\mathrm{Ph} / \mathrm{An}$ ratio value [6-12].

In the northeastern area of Todos os Santos Bay (TSB), Bahia, Brazil, the extraction, transport and refinement of petroleum is the most conspicuous industrial activity[31-32].

The region is bordered by extensive mangrove communities[33], whose characteristics and necessary preservation make it imperative to prevent and/or to determine the extension of any impact[34].

In Brazil, very limited study for the monitoring of PAHs on surface water is performed[35-39]. In order to evaluate the contamination status of PAHs in surface water from estuarine region and Todos os Santos Bay, northern Brazil, an investigation has been performed with a quantitative GC-MS method.

\section{Materials and Methods}

\subsection{Area Description and Sampling}

Todos os Santos Bay is situated on the northern of Brazil. With a population of almost 2,1 million and the surface area of the bay about $1,052 \mathrm{~km}^{2}$, it is a huge commercial and industrial center.

Todos os Santos Bay has a hot and wet climate with distinct four seasons, sufficient sunshine and moderate rainfall. The annual mean temperature is $24^{\circ} \mathrm{C}$ and the annual average rainfall is $2100 \mathrm{~mm}$. The Todos os Santos Bay urban/ industrial complex is highly polluted with the development of industry and rapid urbanization. Industry and automobiles are two major sources of pollution.

Rivers in the Todos os Santos Bay are severely polluted with high loads of persistent inorganic/organic pollutants. According to the Reports of Todos os Santos Bay Environmental Quality in 2004[39], the sewage discharge was 297 million tonnes including 120 million tonnes of industrial effluents and 177 million tonnes of domestic wastewater. Industrial effluent was treated completely by sewage treatment plants (STP); the total treatment ratio of sewage was up to $50 \%$. There are mainly nine rivers in Todos os Santos Bay: Paraguaçu River, Subaé River, Caipe River, Suape River, Jaguaripe River, Açu River, Traripe River, Dona River and
Cachoeirinha River. The surface water samples were collected $(0-10 \mathrm{~cm})$ by using cylinder samplers aboard a chartered vessel during axial surveys on february and july, 2007, and the nineteen locations of sampling sites of surface water are shown in Fig. 1. The data for the master parameters are shown in Table 1.

\subsection{Chemicals}

Standard PAHs (16 compounds specified on EPA Method 610 , each at $100,200,1000$ or $2000 \mu \mathrm{g} / \mathrm{mL}$ ) in a mixture were obtained from Supelco (Bellefonte, PA, USA). These compounds are as follows: naphthalene $(\mathrm{Np})$, metil-naphthalene $(\mathrm{mNp})$, dimetil-naphthalene ( $\mathrm{dNp})$, acenaphthylene (Acy), acenaphthene(Ace), fluorine(F), phenanthrene (Ph), anthracene (An), fluoranthene (Fl), pyrene (Py), chrysene (Chry), benzo[a]anthracene (BaAn), benzo[b]fluoranthene (BbFl), benzo[k]fluoranthene $(\mathrm{BkFl})$, benzo[a]pyrene $(\mathrm{BaPy})$, benzo [g,h,i]perylene (B[ghi] Pe) and dibenzo[a,h] anthracene $(\mathrm{dB}[\mathrm{ah}] \mathrm{An})$. Deuterated internal standards (naphthalene-d8, acenaphthene-d10, phenanthrened 10 and chrysene-d12) were obtained from Sigma-Aldrich.

Working standards of PAHs were prepared by combining the standard mixture with the corresponding IS stock solution, respectively. These solutions were further diluted with dichloromethane to prepare calibration solutions in the range 0.01-10 ng/ $\mu \mathrm{L}$. All solvents used for sample processing and analyses (dichloromethane, ethyl acetate, acetone, hexane and methanol) were analytical grade and further distilled twice to remove impurities.

\subsection{Sample Treatment and Sample Extraction}

After returning to the laboratory, aliquots of the sample $(1.0 \mathrm{~L})$ were filtered through $0.45 \mu \mathrm{m}$ microporous filter membrane under vacuum in order to remove algae, zooplankton and suspended particles and a measured aliquot of an internal standard mixture containing naphthalene-d8, acenaphthene-d10, phenanthrene-d10 and chrysene-d12 was added to each sample. The cartridges were first conditioned with $2 \times 5 \mathrm{~mL}$ of methanol followed by $2 \times 5 \mathrm{~mL}$ of deionized water. Water samples were passed through the cartridges at a flow rate of $6 \mathrm{~mL} / \mathrm{min}$ under vacuum.

Following extraction, the cartridges were eluted with $6 \mathrm{~mL}$ of ethyl acetate, which was combined with an ethyl acetate rinse $(5 \mathrm{~mL})$ from the extraction glassware. After water was removed from the extracts by ashed $\mathrm{Na}_{2} \mathrm{SO}_{4}$, the volume of the extracts was reduced by $\mathrm{N}_{2}$ blow-down in a water bath $\left(35^{\circ} \mathrm{C}\right)$ to a final volume of $1 \mathrm{~mL}$.

\subsection{Sample Analyses}

The analysis was performed on a $50 \mathrm{~m}$ fused-silica column (0.32 mm i.d.) coated with CPSil5-CB (0.25 $\mu \mathrm{m}$ thickness). Helium was used as the carrier gas at a flow rate of $1.5 \mathrm{~mL}$ $\min ^{-1}$ (pressure $0.8 \mathrm{kPa}$ ). The following temperature program was employed: $70^{\circ} \mathrm{C}$ to $280^{\circ} \mathrm{C}$ with ramping at $4^{\circ} \mathrm{C}$ $\mathrm{min}^{-1}$. Injector and detector temperature were held at $320^{\circ} \mathrm{C}$. Detection was monitored by flame ionisation detector (FID). The structure of PAHs was confirmed by gas chromatogra- 
phy coupled to mass spectrometry (trace 2000 GC-MS, Thermo Finnigan, USA). A fused-silica DB-5MS capillary column $(30 \mathrm{~m} \times 0.32 \mathrm{mmi}$.d., $0.25 \mu \mathrm{m}$ film thickness $)$ was used. Helium with a purity of $99.999 \%$ was used as the carrier gas at a constant flow of $1.0 \mathrm{~mL} / \mathrm{min}$. A $2 \mu \mathrm{L}$ volume was injected by applying a hot splitless injection technique. The temperature program of the oven was started at $70{ }^{\circ} \mathrm{C}$ (for 1 min) and increased at a rate $10^{\circ} \mathrm{C} / \mathrm{min}$ to $300^{\circ} \mathrm{C}$ and was held for $10 \mathrm{~min}$. The mass spectrometer was operated in the electronic impact (EI) mode with an ion source at $200^{\circ} \mathrm{C}$ and the electron impact energy was set at $70 \mathrm{eV}$. Identification of the PAH compounds was performed by comparing GC retention time with those of authentic standards. Quantification of individual compounds was based on comparison of peak areas with those of the recovery standards.

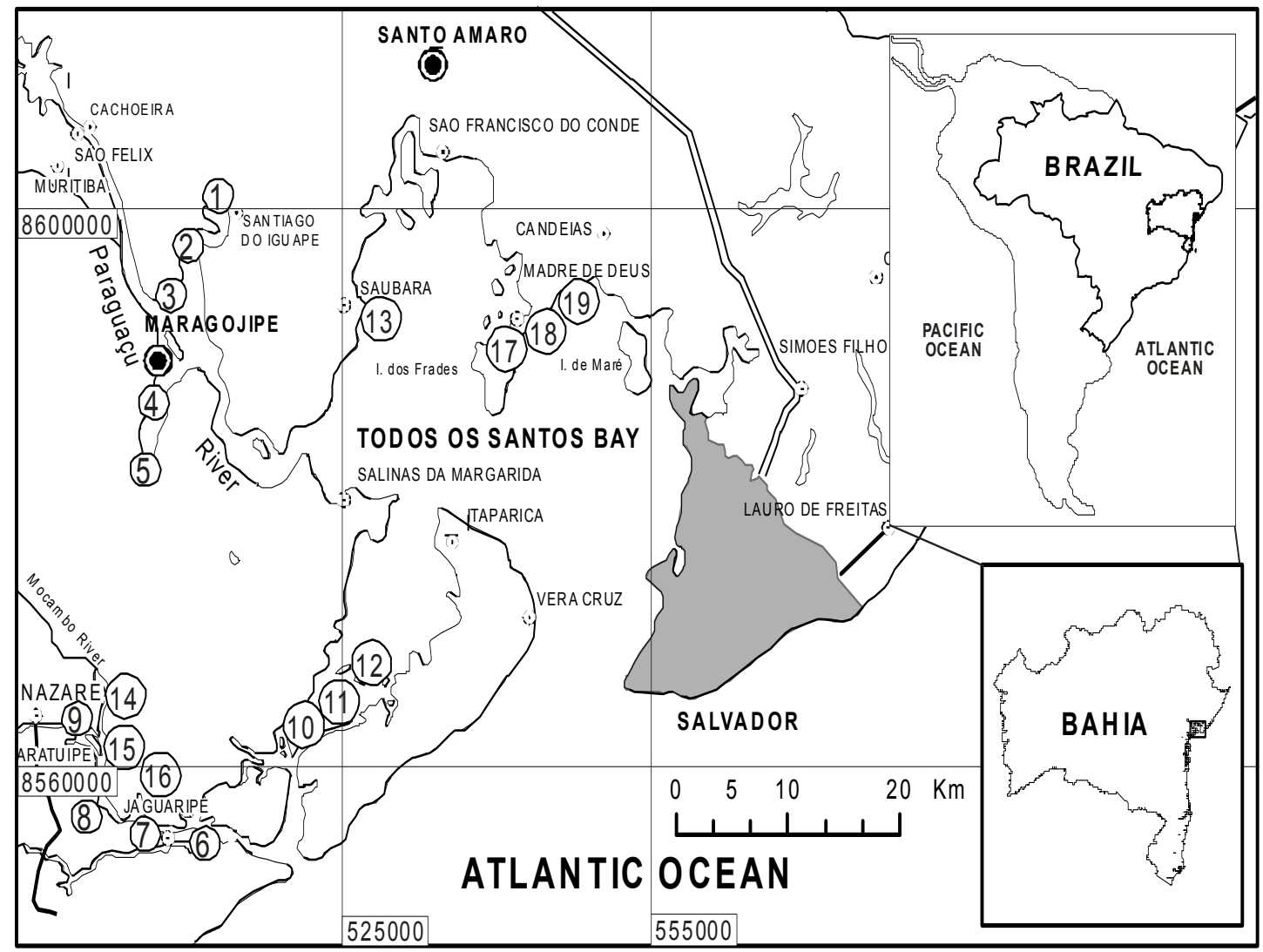

Figure 1. Map of Todos os Santos Bay, Bahia, Brazil, indicate sampling sites of surface water

Table 1. Summary of conditions when water samples were taken from Todos os Santos Bay, Brazil

\begin{tabular}{|c|c|c|c|c|c|}
\hline Station & $\mathrm{pH}$ & Eh & $\mathrm{T}\left({ }^{\circ} \mathrm{C}\right)$ & Salinity & D.O. $(\mathrm{mg} / \mathrm{l})$ \\
\hline 1 & 6,23 & 56 & 35 & 30 & 5,4 \\
\hline 2 & 6,86 & 15 & 35 & 29 & 7,3 \\
\hline 3 & 6,94 & 17 & 34 & 30 & 6,3 \\
\hline 4 & 6,72 & 35 & 33 & 34 & 4,8 \\
\hline 5 & 6,49 & 35 & 36 & 31 & 3,5 \\
\hline 6 & 7,05 & 19 & 29 & 35 & 5,8 \\
\hline 7 & 7,02 & 17 & 30 & 30 & 4,9 \\
\hline 8 & 6,59 & 30 & 30 & 24 & 6,1 \\
\hline 9 & 7,06 & 25 & 29 & 20 & 3,4 \\
\hline 10 & 6,71 & 41 & 25 & 31 & 5,9 \\
\hline 11 & 6,58 & 46 & 25 & 32 & 5,9 \\
\hline 12 & 6,82 & 36 & 25 & 32 & 5,8 \\
\hline 13 & 7,81 & -12 & 28 & 29 & 7,5 \\
\hline 14 & 6,22 & 68 & 26 & 20 & 2,6 \\
\hline 15 & 6,23 & 67 & 26 & 20 & 1,3 \\
\hline 16 & 6,16 & 71 & 28 & 20 & 5,3 \\
\hline 17 & 8,21 & -35 & 29 & 31 & 7,5 \\
\hline 18 & 8,27 & -38 & 29 & 31 & 7,5 \\
\hline 19 & 8,30 & -39 & 30 & 32 & 7,5 \\
\hline
\end{tabular}


Before sample analysis, relevant standards were analyzed to check column performance, peak height and resolution, and the limits of detection (LOD). With each set of samples to be analyzed, a solvent blank, a standard mixture and a procedural blank were run in sequence to check for contamination, peak identification and quantification. Compounds were identified mainly by their retention times.

\subsection{Analytical Quality Controls}

All data were subject to strict quality control procedures. For PAHs, deuterated IS were used to compensate for losses involved in the sample extraction and work-up. The four IS in water were determined with good precision, and their recoveries ranged from $70 \pm 5$ to $93 \pm 10 \%$ for water samples. Detection limits derived from replicate procedural blanks were aproximately $1 \mathrm{ng} / \mathrm{L}$. GC/MS data were acquired and processed by using Xcalibur software.

\subsection{Statistical Treatment}

In order to explore more latent relationships among all the stations investigated, the principal component analysis (PCA) was applied to the obtained results.

PCA reduces the number of variables in the original data set into fewer factors (or principal components) without significant loss in the total variance of the data. The loading that each variable in the original data contributes to the principal components enables grouping of data with similar behaviors[40].

\section{Results and Discussion}

\subsection{PAH Concentrations and Compositional Patterns}

This report presents results from analyses of parent PAHs in Todos os Santos Bay, Brazil. The concentration ranges of individual and total PAHs in surface water are shown in Table 2.

The total PAH concentrations ranged from 0,0029 to $0,1079 \mathrm{ng} / \mathrm{L}$ in surface waters (main rivers, tributaries, etc.) with mean value of $0,0344 \mathrm{ng} / \mathrm{L}$ (Tab. 2). The highest concentration of surface water was observed at station S3, which is situated in the mouth where Iguape River merges into the main river-Paraguaçu River (Fig. 2). With increasingly intense urban and industrial development in Maragojipe, the amount of PAHs detected there is obviously related to urban runoffs, sewage discharges, vehicular exhaust emission and intense shipping activities that were observed during the sampling. Similarly, high concentration $(>0.08 \mathrm{ng} / \mathrm{L})$ was also found at station S5. In addition, there were a lot of industries (e.g. chemical, power) around the study area, many of which were discharging waste effluents; hence, there were many non-point sources in the area, contributing to the very high concentrations of PAHs detected.

Table 2. Range of concentrations (ng/L) of parent PAHs in surface water from Todos os Santos Bay, Brazil. See text for more information

\begin{tabular}{|c|c|c|c|c|c|c|c|}
\hline & Valid N & Mean & Median & Minimum & Maximum & Variance & Std.Dev. \\
\hline $\mathrm{Np}$ & 19 & 0,0010 & 0,0009 & 0,0001 & 0,0055 & 0,0000 & 0,0013 \\
\hline $\mathrm{mNp}$ & 18 & 0,0005 & 0,0003 & 0,0000 & 0,0020 & 0,0000 & 0,0005 \\
\hline $\mathrm{dNp}$ & 15 & 0,0007 & 0,0002 & 0,0000 & 0,0037 & 0,0000 & 0,0012 \\
\hline Acy & 19 & 0,0017 & 0,0002 & 0,0000 & 0,0087 & 0,0000 & 0,0027 \\
\hline Ace & 19 & 0,0004 & 0,0003 & 0,0000 & 0,0015 & 0,0000 & 0,0004 \\
\hline $\mathrm{F}$ & 19 & 0,0026 & 0,0012 & 0,0001 & 0,0271 & 0,0000 & 0,0060 \\
\hline $\mathrm{Ph}$ & 19 & 0,0011 & 0,0010 & 0,0000 & 0,0027 & 0,0000 & 0,0008 \\
\hline An & 16 & 0,0011 & 0,0011 & 0,0001 & 0,0031 & 0,0000 & 0,0009 \\
\hline $\mathrm{Fl}$ & 9 & 0,0124 & 0,0034 & 0,0010 & 0,0570 & 0,0000 & 0,0186 \\
\hline Py & 19 & 0,0045 & 0,0015 & 0,0001 & 0,0266 & 0,0000 & 0,0070 \\
\hline $\mathrm{BaAn}$ & 12 & 0,0030 & 0,0013 & 0,0001 & 0,0159 & 0,0000 & 0,0046 \\
\hline Chry & 13 & 0,0029 & 0,0008 & 0,0001 & 0,0145 & 0,0000 & 0,0049 \\
\hline $\mathrm{BbFl}$ & 10 & 0,0004 & 0,0005 & 0,0000 & 0,0011 & 0,0000 & 0,0003 \\
\hline $\mathrm{BkFl}$ & 8 & 0,0027 & 0,0014 & 0,0007 & 0,0104 & 0,0000 & 0,0033 \\
\hline BaPy & 13 & 0,0146 & 0,0047 & 0,0011 & 0,0592 & 0,0000 & 0,0180 \\
\hline Total PAHs & 19 & 0,0344 & 0,0213 & 0,0029 & 0,1079 & 0,0010 & 0,0314 \\
\hline LMM PAHs & 19 & 0,0088 & 0,0078 & 0,0017 & 0,0280 & 0,0000 & 0,0055 \\
\hline HMM PAHs & 19 & 0,0256 & 0,0119 & 0,0003 & 0,0986 & 0,0010 & 0,0310 \\
\hline $\mathrm{Ph} / \mathrm{An}$ & 16 & 1,0270 & 0,7950 & 0,3812 & 3,0487 & 0,4570 & 0,6763 \\
\hline $\mathrm{BaAn} /(\mathrm{BaAn}+\mathrm{Chry})$ & 13 & 8,2544 & 0,5240 & 0,1942 & 101,0000 & 776,5900 & 27,8674 \\
\hline $\mathrm{Fl} /(\mathrm{Fl}+\mathrm{Py})$ & 9 & 0,5477 & 0,5040 & 0,2841 & 0,9378 & 0,0590 & 0,2436 \\
\hline $\mathrm{An} /(\mathrm{An}+\mathrm{Ph})$ & 16 & 0,5297 & 0,5571 & 0,2470 & 0,7240 & 0,0150 & 0,1223 \\
\hline
\end{tabular}




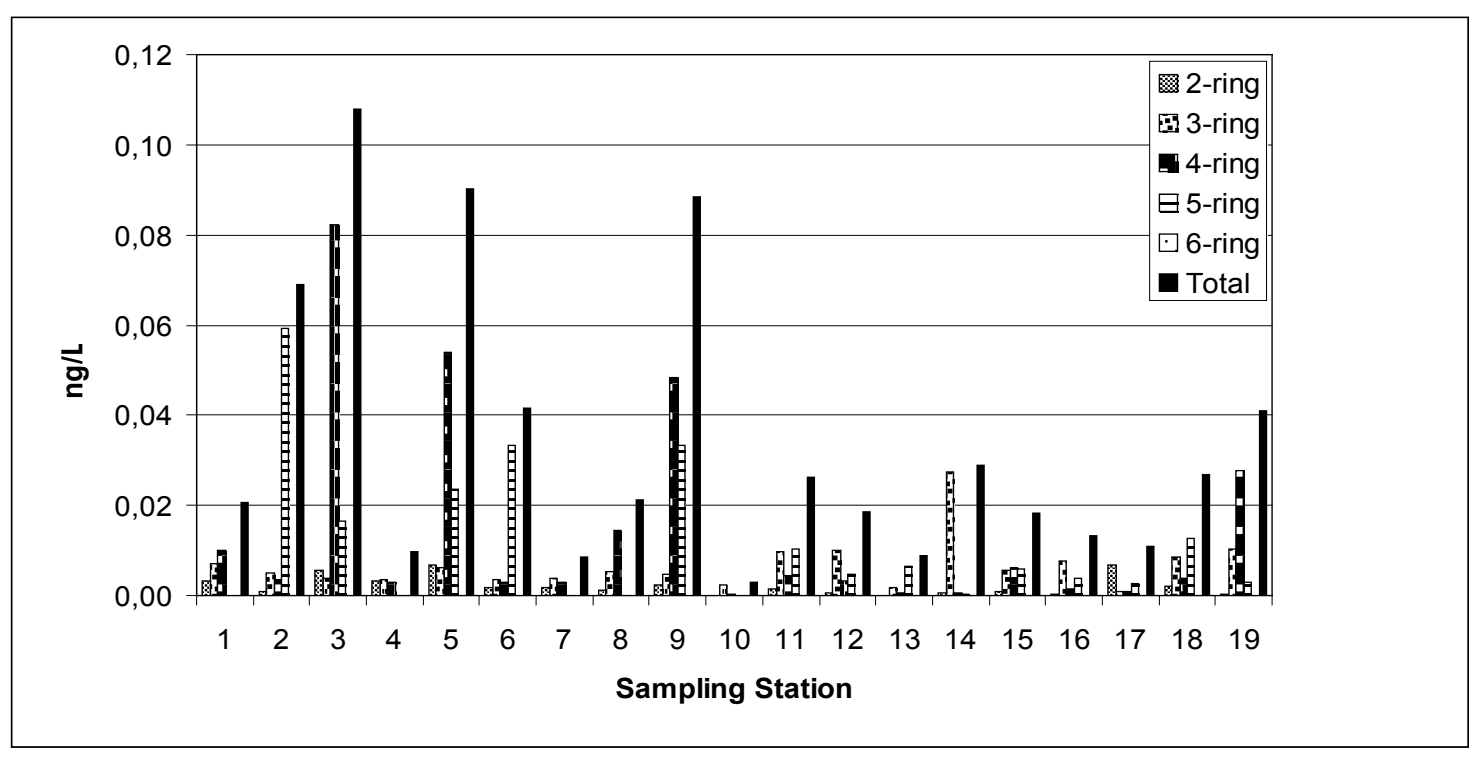

Figure 2. Concentrations (ng/L) of two-, three-, four-, five-, six-ring and total PAHs in the surface water column of Todos os Santos Bay. Two-ring PAHs include naphthalene; three-ring PAHs include acenaphthylene, acenaphthene, fluorene, phenanthrene and anthracene; four-ring PAHs include fluoranthene, pyrene, benzo[a]anthracene and chrysene; five-ring PAHs include benzo[b]fluoranthene, benzo[k]fluoranthene, benzo[a]pyrene and dibenzo[a,h]anthracene; six-ring PAHs include indeno[1,2,3-c,d]pyrene and benzo[g,h,i]perylene

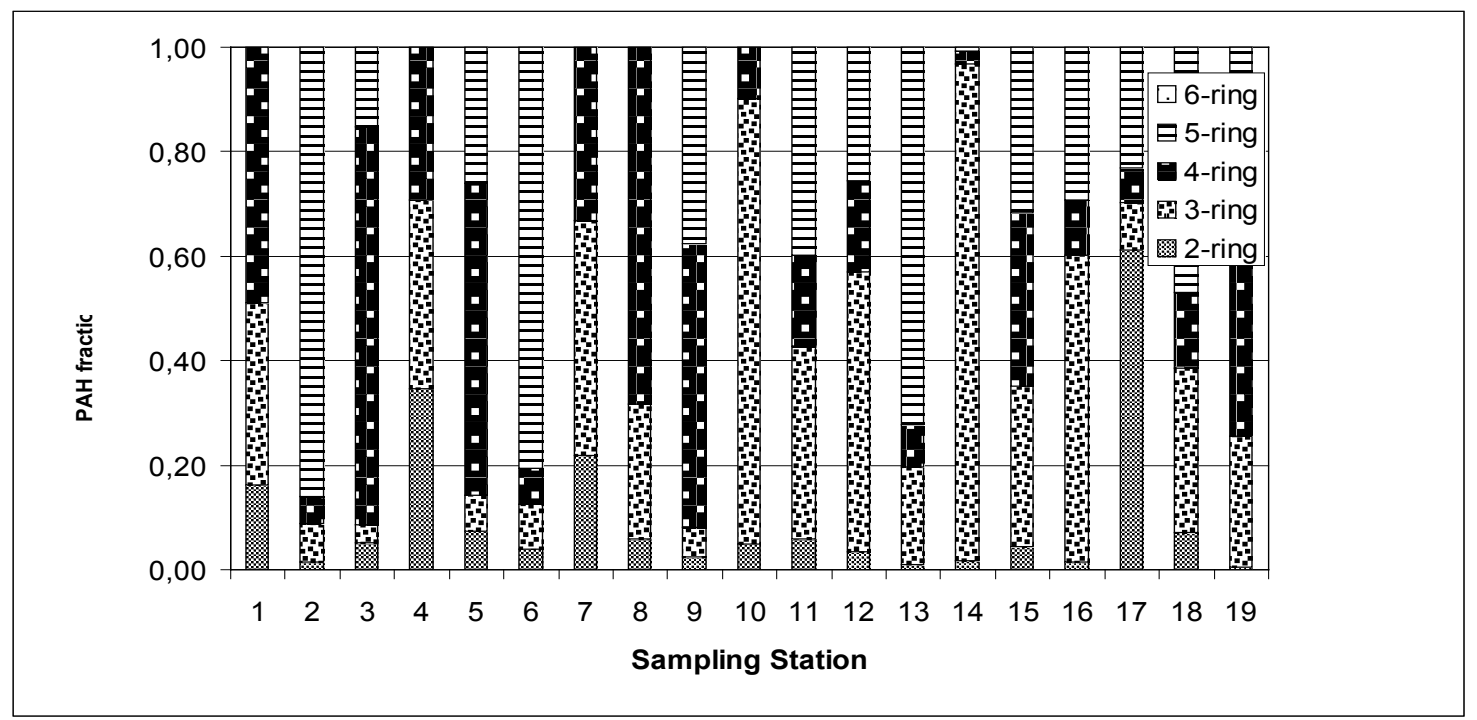

Figure 3. Composition pattern of parent PAHs in surface water of Todos os Santos Bay. Two-ring PAHs include naphthalene; three-ring PAHs include acenaphthylene, acenaphthene, fluorene, phenanthrene and anthracene; four-ring PAHs include fluoranthene, pyrene, benzo[a]anthracene and chrysene; five-ring PAHs include benzo[b]fluoranthene, benzo[k]fluoranthene, benzo[a]pyrene and dibenzo[a,h]anthracene; six-ring PAHs include indeno[1,2,3-c,d]pyrene and benzo[g,h,i]perylene

Table 3. Summary of total parent PAH concentration (ng/L) in surface water from various sites in the world

\begin{tabular}{|c|c|c|c|c|c|}
\hline Location & Date of sampling & $\mathrm{N}^{\mathrm{a}}$ & $\mathrm{n}^{\mathrm{b}}$ & Range(ng/L) & Reference \\
\hline Todos os Santos Bay (Brazil) & February-July 2007 & 19 & 14 & $0.002-0.108$ & This work \\
\hline Northern Greece & July-August 1996 & 8 & 16 & $184-856$ & {$[1]$} \\
\hline Aegean Sea (eastern mediterranean) & & & 14 & $0.113-0.489$ & {$[14]$} \\
\hline Baltic Sea & August 1995 & & 14 & $0.300-0.594$ & {$[14]$} \\
\hline Danube Estuary & August 1995 & 2 & 14 & $0.183-0.214$ & {$[14]$} \\
\hline Seawater around England and Wales & June 1993-July 1995 & 63 & 15 & $<1-24821$ & {$[17]$} \\
\hline
\end{tabular}

${ }^{\mathrm{a}} \mathrm{N}$, number of samples analysed.

${ }^{\mathrm{b}} \mathrm{n}$, number of compounds analyzed.

The compositional pattern of PAH by ring size along the contamination gradient is shown in Fig. 3. It is clear that twoand three-ring PAHs (naphthalene, acenaphthylene, ace- naphthene, fluorene, phenanthrene and anthracene) are the most abundant PAHs, which on average occupied 96 and $10 \%$ of total PAHs in surface water. In addition, four and five-ring 
PAHs on average occupied 90 and $4 \%$ of total PAHs in surface water. Benzo[a]pyrene is one of the most frequently detected compounds in almost all surface water samples (except S1, S4, S7, S8, S10 and S14). Higher proportions (about $90 \%$ of benzo[a]pyrene) were observed at stations S2, $\mathrm{S} 6$ and $\mathrm{S} 13$.

The total PAH concentrations in water found in the study area are four to five orders of magnitude lower than those found in waters in Danube Estuary[14], Aegean[14] and Baltic Sea[14] (Table 3). Concentrations were also lower than total PAH levels detected in northern Greece [1] and Seawater around England and Wales[17].

\subsection{Sources of PAHs}

\subsubsection{Ratio Analysis}

The ratios of $\mathrm{Ph} / \mathrm{An}$ within the two-ring $\mathrm{PAH}$ group and Fl/Py within four-ring PAH group were used to differentiate PAHs of distinct origins. Therefore, $\mathrm{Ph} / \mathrm{An}>15$ for petrogenic sources and $\mathrm{Ph} / \mathrm{An}<10$ for pyrolytic sources. Due to the wide range of values for this index found in literature, values between 10 and 15 are considered indefinite relating to the source $[29,43]$.

Likewise, discrimination also occurs in the fluoranthene/pyrene (Fl/Py) ratio. In petroleum-derived PAHs, pyrene is more abundant than fluoranthene. At higher combustion temperatures a predominance of fluoranthene over pyrene is characteristic. As such, a value greater than 1 is classically related to pyrogenic sources[44]. Hence, in combination, a $\mathrm{Ph} / \mathrm{An}$ ratio value $<10$ and $\mathrm{Fl} / \mathrm{Py}$ ratio $>1$ indicates that PAHs originate from pyrogenic sources[29]. The ratios of $\mathrm{Ph} / \mathrm{An}, \mathrm{Fl} / \mathrm{Py}$ in surface water were calculated and are listed in Table 4. As shown in Table 3, almost all the ratios of $\mathrm{Ph} / \mathrm{An}<15$ and $\mathrm{Fl} / \mathrm{Py}<1$ tended to indicate that PAHs were coming from petrogenic sources.

Table 4. Ratios of phenanthrene/anthracene ( $\mathrm{Ph} / \mathrm{An})$, fluoranthene/pyrene (Fl/Py) in surface water samples from Todos os Santos Bay, Brazil

\begin{tabular}{c|cc} 
Station & $\mathrm{Ph} / \mathrm{An}$ & $\mathrm{Fl} / \mathrm{Py}$ \\
\hline 1 & 0,89 & 0,52 \\
2 & 0,93 & 0,40 \\
3 & 0,77 & 8,81 \\
4 & 1,17 & 2,03 \\
5 & 0,64 & 15,07 \\
6 & 0,54 & 0,96 \\
7 & 0,81 & 1,06 \\
8 & 0,72 & 0,41 \\
9 & 0,78 & 1,02 \\
10 & 3,05 & - \\
11 & - & - \\
12 & - & - \\
13 & 0,68 & - \\
14 & 0,38 & - \\
15 & 0,96 & - \\
16 & 1,50 & - \\
17 & 0,56 & - \\
18 & - & - \\
19 & 2,06 & -
\end{tabular}

\subsubsection{Principal Component Analysis}

Distribution of the normalized PAHs data of surface water to factor coordinates of the variables is shown in Fig. 4. The two principal components selected are able to account for
$46.69 \%$ of total variance of the original data. The first and second PCs in surface water represented 30.01 and $16.68 \%$ of the variability, respectively (Fig.5).

\begin{tabular}{|c|c|c|c|c|}
\hline & ctor 1 & 2 & 3 & 4 \\
\hline $\mathrm{Np}$ & U, & , & & 0,408983 \\
\hline $\mathrm{mNp}$ & 6 & $0,4 J 4535$ & & $-0,618207$ \\
\hline $\mathrm{dNp}$ & 0,12 & 97 & 76 & 506 \\
\hline Acy & $-0,63$ & 70 & 00 & 0,012819 \\
\hline Ace & -0, & $-0,223834$ & 0,236250 & 0108880 \\
\hline $\mathrm{F}$ & $-0,0$ & 0,1 & +9 & 40 \\
\hline $\mathrm{Ph}$ & $-0,037388$ & $-0,716425$ & 0,390563 & 0,274196 \\
\hline An & $-0,68$ & $-0,426$ & 65 & 0,134649 \\
\hline $\mathrm{Fl}$ & -0, & 0,292146 & $-0,092348$ & $-0,087523$ \\
\hline Py & 0, & 3 & $-0,760834$ & 50 \\
\hline $\mathrm{BaAn}$ & 0,414 & $-0,60$ & $-0,1$ & $-0,549912$ \\
\hline Chry & 0,376707 & $-0,593719$ & 0,017962 & $-0,556311$ \\
\hline $\mathrm{BbFl}$ & $-0,8 c$ & $-0,07$ & $-0,318990$ & $-0,17744$ \\
\hline $\mathrm{BkFl}$ & $-0,727831$ & $-0,289672$ & 0,455519 & $-0,018638$ \\
\hline $\mathrm{BaPy}$ & 0,479085 & $-0,319336$ & 0,072423 & $-0,127263$ \\
\hline
\end{tabular}

Figure 4. Factor coordinates of the variables, based on correlations
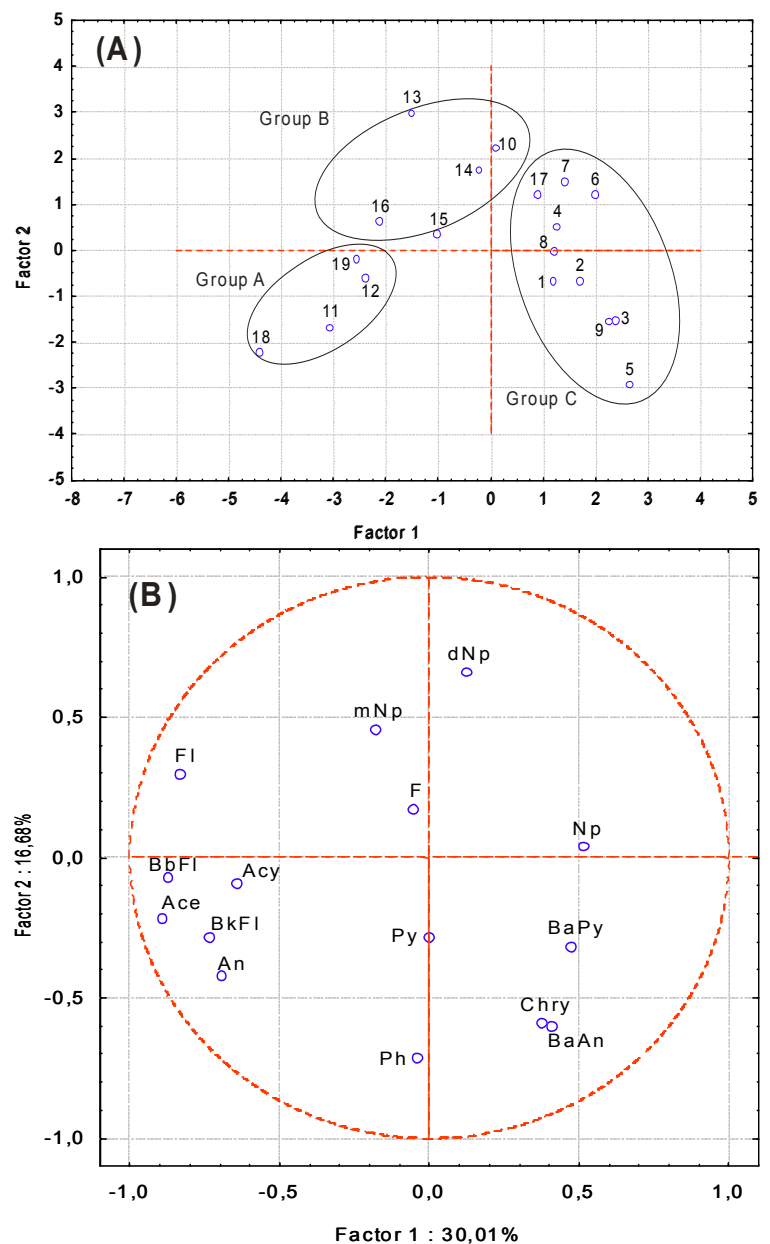

Figure 5. PCA showing the pattern of PAHs in the surface water: (A) factor loading plot and $\mathrm{B}$ ) factor score plot-(Np) naphthalene, (Acy) acenaphthylene, (Ace) acenaphthene, $(\mathrm{F})$ fluorene, $(\mathrm{Ph})$ phenanthrene, $(\mathrm{An})$ anthracene, (Fl) fluoranthene, (Py) pyrene, (Ba) benzo[a]anthracene, (Chy) chrysene, $(\mathrm{BbFl})$ benzo[b]fluoranthene, $(\mathrm{BkFl})$ benzo[k]fluoranthene, $(\mathrm{BaP})$ benzo[a]pyrene and (dAn) dibenzo[a,h]anthracene 
There are three groups discriminated on the factor loading plot (Fig. 5a). Group A clusters samples of stations 11, 12 and 18; group B contains samples collected from stations 10, 13 to 17 and 19; group C, samples collected from stations 1 to 9 .

From Fig. 2, we can see both the samples of stations 11, 12 and 18 collected from the Jaguaripe River and Madre de Deus, probably containing similar contaminants, constituting the group A. As shown in Fig. 5a, group A is characterized by the negative axes of both principal components; on the other hand, from Fig. 5b, this quadrant is dominated by acenaphthylene. It indicated that acenaphthylene contributed significantly to the samples at group $\mathrm{A}$, and the notable contribution of acenaphthylene over the contribution of the other PAHs notability.

The samples of stations 11, 12 and 18 were collected from the places nearby different interchanges, so they cluster together. However, the characteristic of the sample from station 19, is similar to those of samples in group B. The similarity may be caused by their complicated origins of contamination. Nevertheless, the sample of station 17 has some different characteristics from those of the other samples in group B. Contrary to the other samples in group B, the sample of station 17 is characterized by positive loading in the second principal component, so it got more contribution from the naphthalene than the other samples.

The samples for group B got the contribution from fluoranthene mostly among all the PAHs. However, compared with group $\mathrm{C}$, the samples for group $\mathrm{B}$ gave a relatively low contribution to factor 2 , so they got less contribution from naphthalene than group $\mathrm{C}$. This conclusion can be confirmed by fig. 4 .

The sample of station 13 was collected in Saubara, so the characteristic of this sample may be different from the others. As shown in Fig. 5a, the station 13 has a high value of factor 2 and it can be assumed that it is able to get the contribution from something with a high score value of factor 2 , which seems to be the metilnaphthalene, giving the mostly contribution among these PAHs.

\section{Conclusions}

The PAH profiles of water samples revealed that the dominant PAHs were high molecular weight (four- and five ring) PAHs in surface water of Todos os Santos Bay, Brazil including naphthalene, acenaphthylene, acenaphthene, fluorene, phenanthrene and anthracene.

The PAHs in surface water samples originated mainly from petrogenic inputs based on the high proportion of two-ring (naphthalene) and three ring PAHs. Although the calculated ratios of $\mathrm{Ph} / \mathrm{An}, \mathrm{Fl} / \mathrm{Py}$ and principal component analysis are usually performed to analyze the origin of PAHs in sediments, we attempted to apply the ratios and PCA to the surface water in this study. The analysis results showed that the ratios and PCA could be applied to the surface water investigation to some extent.
Oil spill and leakage from boats and ships, vehicular exhaust emission, discharge from municipal and industrial wastewater and runoff might be important sources. It indicates that surface water received anthropogenic PAHs from different sources and although specific sources are known to be responsible for the presence of PAHs in surface waters, their occurrence cannot always be related to a particular source in Todos os Santos Bay, Brazil.

\section{ACKNOWLEDGEMENTS}

The authors are grateful to FINEP - CTPETRO no. 640002700 and JJCelino wishes to thank the Research Foundation of the State of Bahia - FAPESB - for granting him a research scholarship no. 297/2007.

\section{REFERENCES}

[1] R. Barra, P. Popp, R. Quiroz, C. Bauer, H. Cid, W. von Tü mpling, Persistent toxic substances in soils and waters along an altitudinal gradient in the Laja River Basin, Central Southern Chile. Chemosphere 58 (2005) 905-915.

[2] L. Guzzella, G. Poma, A. De Paolis, C. Roscioli, G. Viviano, Organic persistent toxic substances in soils, waters and sedi ments along an altitudinal gradient at Mt. Sagarmatha, Himalayas, Nepal. Environmental Pollution 159 (2011) $2552-2564$

[3] E. Manoli, C. Samara, I. Konstantinou, T. Albanis, Polycyclic aromatic hydrocarbons in the bulk precipitation and surface waters of northern Greece, Chemosphere 41 (2000) 1845-1855.

[4] IARC (International Agency for Research on Cancer), Polynuclear Aromatic Compounds. Part 1. Chemicals. In: IARC Monographs on the Evaluation of the Carcinogenic Risk to Humans, vol. 32. (1983). Environmental and Experimental Data, Lyon, France. http://www.iarc.fr/. Accessed in may/2012.

[5] P. Baumard, H. Budzinski, P. Garrigues, Analytical procedure for the analysis of PAHs in biological tissues by gas chromatography coupled to mass spectrometry: application to mussels, Fresenius J. Anal. Chem. 359 (1997) 502-509.

[6] A.M. Mastral, M.S. Call'en, A review on polycyclic aromatic hydrocarbon $(\mathrm{PAH})$ emissions from energy generation, Environ. Sci. Technol. 34 (2000) 3051-3057.

[7] E. Magi, R. Bianco, C. Ianni, M.D. Carro, Distribution of polycyclic aromatic hydrocarbons in the sediments of the Adriatic Sea, Environ. Pollut. 119 (2002) 91-98.

[8] O.H.J. Szolar, H. Rost, R. Braun, A.P. Loibner, Analysis of polycyclic aromatic hydrocarbons in soil: minimizing sample pretreatment using automated soxhlet with ethyl acetate as extraction solvent, Anal. Chem. 74 (2002) 2379-2385.

[9] P. Schubert, M.M. Schantz, L.C. Sander, S.A. Wise, Determination of polycyclic aromatic hydrocarbons with molecular weight 300 and 302 in environmental-matrix standard reference materials by gas chromatography/mass spectrometry, 
Anal. Chem. 75 (2003) 234-246.

[10] J.H. Clemons, L.M. Allan, C.H. Marvin, Z. Wu, B.E. Mccarry, D.W. Bryant, Evidence of estrogen- and TCDD-like activities in crude and fractionated extracts of PM10 air particulate material using in vitro gene expression assays, Environ. Sci. Technol. 32 (1998) 1853-1860.

[11] G.L. Brun, O.M. Vaidya, M.G. L'eger, Atmospheric deposition of polycylic aromatic hydrocarbons to Atlantic, Canada: geographic and temporal distributions and trends 1980-2001, Environ. Sci. Technol. 38 (2004) 1941-1948.

[12] F.C. Ko, J.E. Baker, Partitioning of hydrophobic organic contaminants to resuspended sediments and plankton in the Mesohaline Chesapeake Bay, Mar. Chem. 49 (1995) 171-188.

[13] S. Mitra, T.S. Bianchi, A preliminary assessment of polycyclic aromatic hydrocarbon distributions in the lower Mississippi River and Gulf of Mexico, Mar. Chem. 82 (2003) 273-288.

[14] R.E. Countway, R.M. Dickhut, E.A. Canuel, Polycyclic aromatic hydrocarbon $(\mathrm{PAH})$ distributions and associations with organic matter in surface waters of the York River, VA Estuary, Org. Geochem. 34 (2003) 209-224.

[15] M.B. Yunker, R.W. Macdonald, D. Goyette, D.W. Paton, B.R. Fowler, D. Sullivan, J. Boyd, Natural and anthropogenic inputs of hydrocarbons to the Strait of Georgia, Sci. Total Environ. 225 (1999) 181-209.

[16] R. Gotz, O.H. Auer, P. Friesel, K. Roch, Organic trace compounds in the water of the River Elbe near Hamburg, Chemosphere 36 (1998) 2103-2118.

[17] C. Maldonado, J.M. Bayona, L. Bodineau, Sources, distribution, water volume processes of aliphatic and polycyclic aromatic hydrocarbons in the northwestern Black Sea water, Environ. Sci. Technol. 33 (1999) 2693-2702.

[18] G. Witt, E. Trost, Polycyclic aromatic hydrocarbons (PAHs) in sediments of the Baltic Sea and of the German coastal waters, Chemosphere 38 (1999) 1603-1614.

[19] G. Witt, H. Siegel, The consequences of the Oder flood in 1997 on the distribution of polycyclic aromatic hydrocarbons (PAHs) in the Oder River estuary, Mar. Pollut. Bull. 40 (2000) 1124-1131.

[20] R.J. Law, V.J. Dawes, R.J. Woodhead, P. Matehiessen, Polycyclic aromatic hydrocarbons (PAH) in wastewater around England and Wales, Mar. Pollut. Bull. 34 (1997) 306-322.

[21] M.B. Fernandes, M.A. Sicre, A. Boireau, J. Tronszynski, Polyaromatic hydrocarbon (PAH) distributions in the Seine River and its estuary, Mar. Pollut. Bull. 34 (1997) 857-867.

[22] T.I.R. Utvik, G.S. Durell, S. Johnsen, Determining produced water originating polycyclic aromatic hydrocarbons in North Sea waters: comparison of sampling techniques, Mar. Pollut. Bull. 38 (1999) 977-989.

[23] G. A. Umbuzeiro, F. Kummrow, D. A. Roubicek, M. Y. Tominaga, Evaluation of the water genotoxicity from Santos Estuary (Brazil) in relation to the sediment contamination and effluent discharges, Environment International 32 (2006) 359 -364 .

[24] H. X. Corseuil , B. I. A. Kaipper, M. Fernandes, Cosolvency effect in subsurface systems contaminated with petroleum hydrocarbons and ethanol. (2004), Water Research 38 (6), pp. 1449-1456.

[25] C. Hamacher, A.P. Xavier de Brito, I.M.R. De Andrade Brüning, A. Wagener, I. Moreira, The determination of PAH by UV-fluorescence spectroscopy in water of Guanabara Bay, Rio de Janeiro, Brazil, Revista Brasileira de Oceanografia 48 (2000), pp. 167-170.

R. Barra, P. Popp, R. Quiroz, C. Bauer, H. Cid, W. von Tümpling, Persistent toxic substances in soils and waters along an altitudinal gradient in the Laja River Basin, Central Southern Chile, Chemosphere 58 (2005) 905-915.

[26] J.J. Celino, A.F.de S.Queiroz, Fonte e grau da contaminação por hidrocarbonetos policíclicos aromáticos (HPAs) de baixa massa molecular em sedimentos da baía de Todos os Santos, Bahia, R. Esc. Minas, Ouro Preto, 59(3): 265-270, jul. set. (2006).

[27] E. Manoli, C. Samara, Polycyclic aromatic hydrocarbons in natural waters: sources, occurrence and analysis, Trends Anal. Chem. 18 (1999) 417-428.

[28] M.I. Badawy, M.A. Emababy, Distribution of polycyclic aromatic hydrocarbons in drinking water in Egypt, Desalination 251 (2010) 34-40.

[29] J.L. Zhou, H.S. Hong, Z.L. Zhang, K. Maskaoui, W.Q. Chen, Multiphase distribution of organic micropollutants in Xiamen Harbour, China, Water Res. 34 (2000) 2132-2150.

[30] A. Wagener, C. Hamacher, C. Farias, J.M. Godoy, A. Scofield, Evaluation of tools to identify hydrocarbon sources in recent and historical sediments of a tropical bay, Marine Chemistry 35 (2010) 140-153.

[31] J.J. Celino, O.M.C. Oliveira, G.M. Hadlich, A.F.S. Queiroz, K.S. Garcia, Assessment of Contamination by Trace Metals and Petroleum Hydrocarbons in Sediments from the Tropical Estuary of Todos os Santos Bay, Brazil. Revista Brasileira de Geociências 38 (2008) 760-767.

[32] N. Venturini, P. Muniz, M.C. Bicego, C.C. Martins, L.R. Tomasi, Petroleum contamination impact on macro-benthic communities under the influence of an oil refinery: Integrating chemical and biological multivariate data, Estuarine, Coastal and Shelf Science 78 (2008) 457-467.

[33] G.M. Hadlich, J.M. Ucha, J.J. Celino, Apicuns na Baía de Todos os Santos: Distribuição Espacial, Descrição e Caracterização Física e Química. In: Queiroz, Antônio Fernando de Souza ; Celino, Joil José. (Org.). Avaliação de ambientes na Baía de Todos os Santos: aspectos geoquímicos, geofísicos e biológicos. 1 ed. Salvador: EDUFBA, 1 (2008) 59-72.

http://www.recupetro.ufba.br/proamb/LIVRO\%20PROAMB -RECUPETRO Ba\%C3\%ADa\%20de\%20Todos\%20os\%20 Santos,\%20Bahia.pdf Accessed in may/2012.

[34] J.J. Celino, H.X. Corseuil, M. Fernandes, K.S. Garcia, Distribution and Sources of Polycyclic Aromatic Hydrocarbons in the Aquatic Environment: A Multivariate Analysis. Revista da Escola de Minas (Impresso) 63 (2010) 211-218.

[35] CETESB (Companhia de Tecnologia de Saneamento Ambiental). Relatório Técnico, Poluição das Águas na Baía de Santos e Estuários de Santos e São Vicente; 1979.

[36] CETESB (Companhia de Tecnologia de Saneamento Ambiental). Relatório Técnico, Metais pesados na Baía de Santos e Estuários de Santos e São Vicente; 1981. 
[37] CETESB (Companhia de Tecnologia de Saneamento Ambiental). Relatório Técnico, Contaminantes na Bacia do rio Cubatão e seus Reflexos na Biota Aquática; 1990.

[38] CETESB (Companhia de Tecnologia de Saneamento Ambiental). Relatório Sistema Estuarino Santos São Vicente - Agosto de 2001. Available from <www.cetesb.sp.gov.br/A gua/agua_geral.asp/>; 2001.

[39] CRA (Centro de Recursos Ambientais). Relatório Técnico, Diagnóstico do Grau de Contaminação da Baía de Todos os Santos por Metais Pesados e Hidrocarbonetos de Petróleo a partir da Análise das suas Concentrações nos Sedimentos de Fundo e na Biota Associada; 2004.

[40] M.K. Reid, K.L. Spencer, Use of principal components analysis (PCA) on estuarine sediment datasets: The effect of data pre-treatment, Environmental Pollution 157 (2009) $2275-2281$.

[41] Z.L. Zhang, M.H. Dai, H.S. Hong, J.L. Zhou, G. Yu, Dissolved insecticides and polychlorinated biphenyls in the Pearl River Estuary and South China Sea, J. Environ. Monit. 4 (6) (2002) 922-928.

[42] WHO, Polynuclear Aromatic Hydrocarbons. Guidelines for Drinking-Water Quality, second ed., addendum to vol. 2, Health Criteria and Other Supporting Information, World
Health Organization, Geneva, 1998, pp. 123-152.

[43] M.G. Barron, T. Podrabsky, S. Ogle, R.W. Ricker, Are aromatic hydrocarbons the primary determinant of petroleum toxicity to aquatic organisms? Aquat. Toxicol. 46 (1999) 253-268.

[44] M.B. Yunker, R.W. Macdonald, R. Vigarzan, R.H. Mitchell, D. Goyette, S. Sylvestre, PAHs in the Fraser River basin: a critical appraisal of $\mathrm{PAH}$ ratios as indicators of $\mathrm{PAH}$ source and composition, Org. Geochem. 33 (2002) 489-515.

[45] G.P. Yang, Polycylic aromatic hydrocarbons in the sediments of the South China Sea, Environ. Pollut. 108 (2000) 163-171.

[46] N.F.Y. Tam, L. Ke, X.H. Wang, Y.S. Wong, Contamination of polycyclic aromatic hydrocarbons in surface sediments of mangrove swamps, Environ. Pollut. 114 (2001) 255-263.

[47] S.R.G. Barreto, J. Nozaki, E. De Oliveira, V.F.D.N. Filho, P.H.A. Aragão, I.S. Scarminio, W.J. Barreto, Comparison of metal analysis in sediments using EDXRF and ICP-OES with the $\mathrm{HCl}$ and Tessie extraction methods, Talanta 64 (2004) $345-354$.

[48] M. Otto, Chemometrics: Statistics and Computer Application in Analytical Chemistry, Wiley/VCH, Weinheim/New York/Chichester/Brisbane/Singapore/Matthis/Toronto, 1999. 